Section Editor

Mitchell S.V. Elkind,

MD, MS

Bethanie Morgan-

Followell, MD

Emily de los Reyes, MD

Correspondence to

Dr. Morgan-Followell:

bethanie.morgan@

nationwidechildrens.org

\section{Child Neurology:}

\section{Diagnosis of Lambert-Eaton myasthenic syndrome in children}

ABSTRACT

Objective: To report a case of Lambert-Eaton myasthenic syndrome (LEMS) in a child and review the existing literature of LEMS in children.

Methods: We report a pediatric case of LEMS with the classic clinical triad of proximal weakness, autonomic dysfunction, and areflexia; the characteristic increment in compound motor action potential on high-frequency repetitive nerve stimulation; and positive serum P/Q-type voltagegated calcium channel antibodies. Only 11 pediatric cases of LEMS have been reported in the literature.

Results: The patient's presentation with LEMS led to the diagnosis of occult neuroblastoma. Based on review of the existing pediatric literature, no consistent clinical or electrodiagnostic criteria exist to diagnose LEMS in children.

Conclusions: There exists a need for consistent clinical criteria and electrodiagnostic testing for prompt diagnosis of LEMS in children. Prompt identification of LEMS will alert the physician to search for malignancy or another immune-mediated process. Neurology ${ }^{\circledR}$ 2013;80:e220-e222

\section{GLOSSARY}

CMAP = compound motor action potential; LEMS = Lambert-Eaton myasthenic syndrome

Paraneoplastic syndromes are immune-mediated phenomena that occur in a location remote to the primary neoplasm. The incidence of these syndromes is rare in adult cancers. The incidence is unknown in the pediatric population.

Lambert-Eaton myasthenic syndrome (LEMS) is an immune-mediated disorder of neuromuscular transmission. The classic clinical presentation is proximal weakness, areflexia, and autonomic dysfunction. Antibodies to the P/Q-type voltage-gated calcium channel are present in 85\%-90\% of adult patients with LEMS. ${ }^{1}$ These antibodies interfere with quantal acetylcholine release from the presynaptic terminal of the neuromuscular junction and functional loss of voltage-gated calcium channels. Thus, less calcium enters the presynaptic terminal with the action potential, resulting in decreased release of acetylcholine. Nerve conduction studies characteristically show low compound motor action potential (CMAP) amplitudes. ${ }^{1}$ Facilitation, or an incremental increase in the amplitude of the CMAP, is seen upon high-frequency repetitive stimulation or following exercise testing. This is a finding highly specific for LEMS. ${ }^{1}$

LEMS is a rare disorder in adults, most often seen as a paraneoplastic process with small-cell lung cancer. LEMS is even rarer in children, and only 11 pediatric cases have been reported in the literature (table). ${ }^{2-10}$ Neoplasm was associated with 4 of these cases. ${ }^{4,6}$

We present the case of a 3-year-old boy with LEMS, supported by the clinical presentation, characteristic findings on EMG, and elevated serum P/Q-type voltage-gated calcium channel antibodies.

Case report. A previously healthy 3-year-old boy was admitted for evaluation of proximal weakness and ptosis, and for treatment of severe constipation that developed over a 4- to 5-month period. CSF was normal. MRI of the brain was unremarkable. The child's ptosis and extremity weakness improved without treatment over several days and he was discharged home. He returned approximately 1 week later with quadriparesis, worsened ptosis, and areflexia in the lower extremities.

From the Division of Child Neurology, Nationwide Children's Hospital, The Ohio State University, Columbus.

Go to Neurology.org for full disclosures. Funding information and disclosures deemed relevant by the authors, if any, are provided at the end of the article. 


\begin{tabular}{|c|c|c|c|c|c|c|c|c|}
\hline Table & Pedia & ric LEMS cases repor & ted in the litera & ture & & & & \\
\hline Reference & Age & Symptoms & $\begin{array}{l}\text { Underlying } \\
\text { disease }\end{array}$ & CMAP & $\begin{array}{l}\text { Low-frequency } \\
\text { RNS }\end{array}$ & $\begin{array}{l}\text { High-frequency RNS or } \\
\text { postexercise testing }\end{array}$ & Antibodies & Follow-up \\
\hline 2 & $11 \mathrm{y}$ & $\begin{array}{l}\text { Proximal weakness, } \\
\text { areflexia }\end{array}$ & None & Low & Decrement at $3 \mathrm{~Hz}$ & $\begin{array}{l}82 \% \text { increment } \\
\text { postexercise }\end{array}$ & VGCC Ab present & $3.5 y$ \\
\hline 3 & $7 y$ & $\begin{array}{l}\text { Proximal weakness, } \\
\text { areflexia, ptosis, } \\
\text { ophthalmoplegia }\end{array}$ & $\begin{array}{l}\text { Burkitt } \\
\text { lymphoma }\end{array}$ & $\begin{array}{l}\text { "Compatible with } \\
\text { LEMS" }\end{array}$ & $\begin{array}{l}\text { "Compatible with } \\
\text { LEMS" }\end{array}$ & $\begin{array}{l}\text { "Compatible with } \\
\text { LEMS" }\end{array}$ & No VGCC antibodies & $3 \mathrm{mo}$ \\
\hline 4 & $3 y$ & Ptosis, ophthalmoplegia & Neuroblastoma & Not stated & Normal & Normal & VGCC not tested & $1 y$ \\
\hline 4 & $2 y$ & Ptosis & Neuroblastoma & Normal & Not performed & Not performed & VGCC not tested & $2 \mathrm{mo}$ \\
\hline 5 & $10 y$ & Proximal weakness & $\begin{array}{l}\text { Autoimmune } \\
\text { disease }\end{array}$ & Low & Not stated & Increment postexercise & VGCC Ab present & $\begin{array}{l}\text { Not } \\
\text { stated }\end{array}$ \\
\hline 6 & $13 \mathrm{mo}$ & $\begin{array}{l}\text { Proximal weakness, } \\
\text { constipation, ptosis, } \\
\text { ophthalmoplegia }\end{array}$ & Neuroblastoma & Normal & Not performed & Not performed & $\begin{array}{l}\text { No Ach receptor } A b \text {; } \\
\text { VGCC } A b \text { not stated }\end{array}$ & $2 \mathrm{mo}$ \\
\hline 7 & $10 y$ & Proximal weakness & None & Low & Not performed & $\begin{array}{l}62 \% \text { increment } \\
\text { postexercise; } 124 \% \\
\text { increment at } 50 \mathrm{~Hz}\end{array}$ & P/Q VGCC Ab present & $2 y$ \\
\hline 8 & $13 y$ & Proximal weakness & None & Normal & $\begin{array}{l}45 \% \text { decrement at } \\
3 \mathrm{~Hz}\end{array}$ & $\begin{array}{l}42 \% \text { increment at } 50 \\
\mathrm{~Hz}\end{array}$ & Not stated & $1 y$ \\
\hline 9 & $9 y$ & $\begin{array}{l}\text { Proximal weakness, } \\
\text { hyporeflexia }\end{array}$ & None & Normal & Not stated & Increment at $20 \mathrm{~Hz}$ & Not stated & $8 \mathrm{mo}$ \\
\hline 10 & $4 y$ & Hypotonia, areflexia & None & Low peroneal & $\begin{array}{l}33 \% \text { decrement at } \\
1 \mathrm{~Hz}\end{array}$ & $\begin{array}{l}>2000 \% \text { increment at } \\
20-50 \mathrm{~Hz}\end{array}$ & Not stated & $\begin{array}{l}\text { Not } \\
\text { stated }\end{array}$ \\
\hline
\end{tabular}

Abbreviations: $\mathrm{Ab}=$ antibody; $\mathrm{Ach}=$ acetylcholine; CMAP = compound motor action potential; LEMS = Lambert-Eaton myasthenic syndrome; RNS = repetitive nerve stimulation; VGCC = voltage-gated calcium channel.

Initial nerve conduction studies and EMG were normal. Plasma exchange was initiated as the evaluation continued due to suspicion of an immune-mediated process. The child had notable improvement in clinical symptoms following the first 2 plasma exchanges.

Repeat EMG with repetitive nerve stimulation showed 31\% decrement in CMAP with low-frequency stimulation and $278 \%$ increment with high-frequency stimulation. Paraneoplastic antibody panel was positive for P/Q-type voltage-gated calcium channel antibodies. No other autoantibodies were present.

CT of the chest and thorax showed a small paraspinal mass. MRI of the chest and abdomen confirmed the presence of a small left paraspinal mass at L3-L4 extending into the neural foramina. The mass was resected and pathologic examination was consistent with a neuroblastoma with favorable histopathology. Following 7 plasma exchanges and resection of the tumor, the patient's strength improved and ptosis resolved. At 3 years post presentation, the patient is well and without any neurologic deficits.

DISCUSSION The incidence of LEMS is unknown in children. Its incidence in adults is 0.48 per million. ${ }^{1}$ The incidence of LEMS in adults is rising, most likely related to recognition of the syndrome. The cancer most commonly associated with LEMS is small-cell lung cancer. Other malignancies associated with LEMS may have characteristics similar to small-cell lung cancer, including neuroendocrine origin. ${ }^{1}$ In addition to our case, 3 other cases of LEMS related to neuroblastoma have been reported. ${ }^{4,6}$ In non-tumor-associated LEMS, there may be a genetic predisposition to an autoimmune phenotype. A correlation with HLAB8 and HLADR3 and non-tumor-associated LEMS has been shown in adults. ${ }^{1}$ No such associations have been reported in children.

There is no single confirmatory test for LEMS. Diagnosis is based on clinical signs and symptoms, electrophysiologic studies, and testing for serum P/Q-type voltage-gated calcium channels. The classic clinical triad for LEMS consists of proximal muscle weakness, hyporeflexia, and autonomic dysfunction. ${ }^{1}$ Proximal muscle weakness is commonly seen in the lower extremities. As opposed to myasthenia gravis, weakness typically progresses in a proximal to distal and caudal to cranial fashion. ${ }^{1}$ In contrast to Guillain-Barré syndrome, no sensory changes are present and weakness progresses proximally to distally as opposed to beginning distally and ascending. ${ }^{1}$ It is unclear whether autonomic dysfunction was not a prominent feature or was an underrecognized feature of LEMS as reported in the pediatric literature.

One confounding factor in the diagnosis of LEMS is that postexercise facilitation may allow transient return of deep tendon reflexes and an improvement in proximal strength. ${ }^{1}$ Nerve conduction studies characteristically show low CMAP amplitude. In addition, facilitation may not be seen initially. A low CMAP is nonspecific and may be seen clinically in combination with areflexia or hyporeflexia in polyneuropathies such as Guillain-Barré syndrome. 
On repetitive nerve stimulation, a decrement in CMAP amplitude of $\geq 10 \%$ at low-frequency stimulation and an increment in CMAP amplitude of $\geq 100 \%$ at either high-frequency stimulation or postexercise testing are sensitive and specific for LEMS. Postexercise CMAP amplitude increment at high frequency of stimulation is perhaps more specific for LEMS than is repetitive nerve stimulation. ${ }^{1}$

Testing for serum P/Q-type voltage-gated calcium channel antibodies is being done with increasing frequency in suspected cases of LEMS in adults. In adults, 85\%-90\% of patients with LEMS have serum P/Q-type voltage-gated calcium channel antibodies. This number is higher in cases with underlying small-cell lung cancer. Antibody testing was not routinely performed in the cases of LEMS in the pediatric literature. Of the 11 cases reported, however, 4 of these had positive voltage-gated calcium channel antibodies. ${ }^{2,5,7}$ Thus, the value of testing for P/Q-type voltage-gated calcium channel antibodies in children with suspected LEMS is unclear but may be helpful in circumstances where the diagnosis is unclear.

No uniform set of criteria exists for diagnosis of LEMS in children. Most of the reported cases used the combination of clinical signs and symptoms and electrophysiologic testing as the basis for diagnosis. However, in 2 cases, the EMG was suggestive of a myasthenic syndrome and one was normal. ${ }^{4}$ Another case showed normal nerve conduction. ${ }^{6}$ It is not stated whether repetitive nerve stimulation or exercise testing was performed in these cases. Due to the high sensitivity and specificity of the characteristic findings of LEMS in adults on electrophysiologic testing, it seems appropriate that repetitive nerve stimulation or exercise testing should be incorporated into the pediatric diagnostic algorithm for LEMS. The utility of testing for P/Q-type voltage-gated calcium channel antibodies for suspected LEMS in children is unclear due to the small number of cases reported.

The association of LEMS in children with cancer is unclear. Malignancy appears to be less common in pediatric patients with LEMS ( 4 of 11 cases). ${ }^{3,4,6} \mathrm{How}-$ ever, due to the short follow-up in these cases (mean 13 months), one cannot exclude the possibility of later development of cancer. In a study of 100 consecutive adults diagnosed with LEMS and subsequently smallcell lung carcinoma, 96\% were diagnosed with cancer within the first year of symptoms. ${ }^{11}$ Current guidelines for tumor screening in paraneoplastic syndromes state that screening for 2 years postdiagnosis of LEMS in adults is sufficient. ${ }^{12}$ There are insufficient data in the pediatric literature to make any such recommendations; however, based on adult literature, a screening period of at least 2 years for neoplasm in children with LEMS is prudent. In addition, screening for autoimmune disorders is reasonable given the adult literature on nontumor LEMS and a pediatric case report of LEMS in the setting of autoimmune disease. ${ }^{5}$
LEMS is an immune-mediated syndrome that rarely affects children. Diagnosis of LEMS in children should be based on the characteristic clinical presentation and on electrodiagnostic studies. The presence of serum P/Q-type calcium channel antibodies is supportive of the diagnosis of LEMS. LEMS may be associated with malignancy and autoimmune disease in children. In children without identifiable malignancy at presentation, screening for autoimmune disease and close surveillance for development of cancer for at least 2 years should be performed.

\section{AUTHOR CONTRIBUTIONS}

Dr. Morgan-Followell is the primary author of the manuscript. Dr. de los Reyes was involved in the drafting and revision of the manuscript.

\section{STUDY FUNDING}

No targeted funding reported.

\section{DISCLOSURE}

The authors report no disclosures relevant to the article. Go to Neurology.org for full disclosures.

\section{REFERENCES}

1. Titulaer MJ, Lang B, Verschuuren J. Lambert-Eaton myasthenic syndrome: from clinical characteristics to therapeutic strategies. Lancet Neurol 2011;10:1098-1107.

2. Kostera-Pruszczyk A, Ryniewicz B, Rowinska-Marcinska K, Dutkiewicz M, Kaminska A. Lambert-Eaton myasthenic syndrome in childhood. Eur J Paediatr Neurol 2009;13:194-196.

3. Argov Z, Shapira Y, Averbuchheller L, Wirguin I. LambertEaton myasthenic syndrome (LEMS) in association with lymphoproliferative disorders. Muscle Nerve 1995;18: 715-719.

4. Bosdure E, Attarian S, Mancini J, Mikaeloff Y, Chabrol B. Lambert-Eaton myasthenic syndrome revealing neuroblastoma in 2 children. Arch Pediatr 2006;13:1121-1124.

5. Hoffman WH, Helman SW, Sekul E, Carroll JE, Vega RA. Lambert-Eaton myasthenic syndrome in a child with an autoimmune phenotype. Am J Med Genet A 2003;119A:77-80.

6. Roessingh ASD, Loriot $\mathrm{MH}$, Wiesenauer C, Lallier M. Lambert-Eaton myasthenic syndrome revealing an abdominal neuroblastoma. J Pediatr Surg 2009;44:E5-E7.

7. Tsao CY, Mendell JR, Friemer ML, Kissel JT. Lambert-Eaton myasthenic syndrome in children. J Child Neurol 2002;17: 74-76.

8. Dahl DS, Sato S. Unusual myasthenic state in a teen-age boy. Neurology 1974;24:897-901.

9. Chelmickaschorr E, Bernstein LP, Zurbrugg EB, Huttenlocher PR. Eaton-Lambert syndrome in a 9-yearold girl. Arch Neurol 1979;36:572-574.

10. Bady B, Chauplannaz G, Carrier H. Congenital LambertEaton myasthenic syndrome. J Neurol Neurosurg Psychiatry 1987;50:476-478.

11. Titulaer MJ, Wirtz PW, Willems LNA, van Kralingen KW, Smitt P, Verschuuren J. Screening for small-cell lung cancer: a follow-up study of patients with Lambert-Eaton myasthenic syndrome. J Clin Oncol 2008;26:4276-4281.

12. Titulaer MJ, Soffietti R, Dalmau J, et al. Screening for tumours in paraneoplastic syndromes: report of an EFNS Task force. Eur J Neurol 2011;18:19-E13. 


\section{Neurology}

Child Neurology: Diagnosis of Lambert-Eaton myasthenic syndrome in children Bethanie Morgan-Followell and Emily de los Reyes

Neurology 2013;80;e220-e222

DOI 10.1212/WNL.0b013e318293e14e

This information is current as of May 20, 2013

\section{Updated Information \&} Services

References

Subspecialty Collections

Permissions \& Licensing

Reprints including high resolution figures, can be found at: http://n.neurology.org/content/80/21/e220.full

This article cites 12 articles, 3 of which you can access for free at: http://n.neurology.org/content/80/21/e220.full\#ref-list-1

This article, along with others on similar topics, appears in the following collection(s):

All clinical neurophysiology

http://n.neurology.org/cgi/collection/all_clinical_neurophysiology All Pediatric

http://n.neurology.org/cgi/collection/all_pediatric

Lambert-Eaton syndrome

http://n.neurology.org/cgi/collection/lamberteaton_syndrome

Paraneoplastic syndrome

http://n.neurology.org/cgi/collection/paraneoplastic_syndrome

Information about reproducing this article in parts (figures,tables) or in its entirety can be found online at:

http://www.neurology.org/about/about_the_journal\#permissions

Information about ordering reprints can be found online:

http://n.neurology.org/subscribers/advertise

Neurology ${ }^{\circledR}$ is the official journal of the American Academy of Neurology. Published continuously since 1951, it is now a weekly with 48 issues per year. Copyright () 2013 American Academy of Neurology. All rights reserved. Print ISSN: 0028-3878. Online ISSN: 1526-632X.

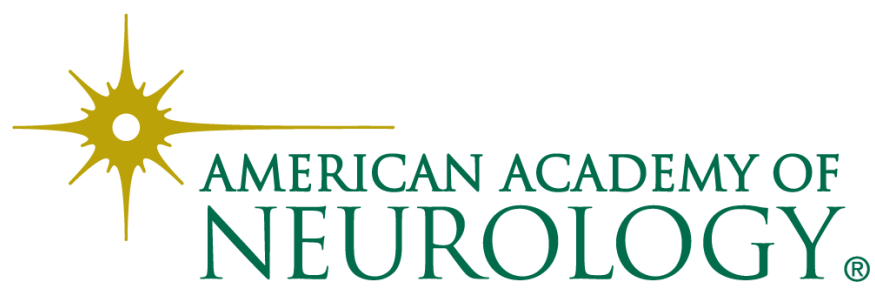

